\title{
Faecal Indicator Bacteria: Groundwater Dynamics and Transport Following Precipitation and River Water Infiltration
}

\author{
Rebecca M. Page • Stefan Scheidler • Elif Polat • \\ Paul Svoboda $\cdot$ Peter Huggenberger
}

Received: 21 July 2011 / Accepted: 20 December 2011 /Published online: 12 January 2012

(C) Springer Science+Business Media B.V. 2012

\begin{abstract}
Faecal contamination of drinking water extracted from alluvial aquifers can lead to severe problems. River water infiltration can be a hazard for extraction wells located nearby, especially during high discharge events. The high dimensionality of river-groundwater interaction and the many factors affecting bacterial survival and transport in groundwater make a simple assessment of actual water quality difficult. The identification of proxy indicators for river water infiltration and bacterial contamination is an important step in managing groundwater resources and hazard assessment. The time resolution of microbial monitoring studies is often too low to establish this relationship. A proxy-based approach in such highly dynamic
\end{abstract}

\footnotetext{
R. M. Page $(\bowtie) \cdot$ S. Scheidler $\cdot$ P. Huggenberger

Department of Environmental Sciences,

Applied and Environmental Geology,

Institute of Geology and Paleontology, University of Basel,

Bernoullistrasse 32,

4056 Basel, Switzerland

e-mail: rebecca.page@unibas.ch

E. Polat

Swiss Tropical and Public Health Institute,

University of Basel,

Socinstrasse 57,

4051 Basel, Switzerland

P. Svoboda

Cantonal Laboratory Basel-Landschaft,

Gräubernstrasse 12,

4110 Liestal, Switzerland
}

systems requires in-depth knowledge of the relationship between the variable of interest, e.g. river water infiltration, and its proxy indicator. In this study, continuously recorded physico-chemical parameters (temperature, electrical conductivity, turbidity, spectral absorption coefficient, particle density) were compared to the counts for faecal indicator bacteria, Escherichia coli and Enterococcus sp. obtained from intermittent sampling. Sampling for faecal indicator bacteria was conducted on two temporal scales: (a) routine bi-weekly monitoring over a month and (b) intense (bi-hourly) event-based sampling over 3 days triggered by a high discharge event. Both sampling set-ups showed that the highest bacterial concentrations occurred in the river. E. coli and Enterococcus sp. concentrations decreased with time and length of flow path in the aquifer. The event-based sampling was able to demonstrate differences in bacterial removal between clusters of observation wells linked to aquifer composition. Although no individual proxy indicator for bacterial contamination could be established, it was shown that a combined approach based on time-series of physico-chemical parameters could be used to assess river water infiltration as a hazard for drinking water quality management.

Keywords Faecal indicator bacteria - Groundwater Drinking water $\cdot$ River-water infiltration . Multiparametric time-series 


\section{Introduction}

Groundwater is an important source of drinking water in many countries, providing approximately $50 \%$ of global drinking water supply, as well as a significant part of water required for industrial and agricultural purposes (Zektser and Everett 2004). Industrial and urban development has increased the pressure on aquifers, leading to degradation of both the quality and the availability of groundwater (Foster and Chilton 2003). Faecal contamination of groundwater is a major concern for municipal water suppliers with low treatment levels and can lead to severe disease outbreaks (Kukkula et al. 1997; Nichols et al. 2009).

The banks and bed of rivers act as a primary barrier to infiltration by river water and many river-borne contaminants. The filter capacity of the aquifer material further reduces the contaminant load as water passes through the subsurface matrix, so that water extracted from wells near rivers can satisfy the quality standards for drinking water during average flow and surface water quality conditions (Regli et al. 2003; Taylor et al. 2004). However, increased bed sheer stresses and related turbulence during high discharge events lead to the sorting out of fine sediments, mobilisation of the river bed and an increase in river water infiltration (Mutiti and Levy 2010). High discharge events alter the water depth in the river, leading to a greater inundated area and gradients between the river and groundwater favouring infiltration. In addition to increased connectivity and infiltration, waterborne pathogenic bacteria concentrations in river water can be up to several orders of magnitude higher during storm events than during base flow conditions (Regli et al. 2003; McKergow and Davies-Colley 2010). In consequence, groundwater quality is severely degraded, so that drinking water extraction cannot be continued and alternative sources need to be used or 'boil water' warnings issued (Regli et al. 2003).

Some drinking water suppliers make use of decision support or simple surveillance systems to manage groundwater extraction. The arrival time of infiltrating water at the extraction wells is dependent on a number of hydrogeological and hydrological properties, rendering a complex pattern in space and time (Krause et al. 2007). Groundwater flow simulations can help to delineate well capture or well-head protection areas (WHPA), upon which management decisions are then based. As bacteria can be transported faster than the average pore-water velocity (Unc and Goss 2003; Taylor et al. 2004), many WHPA may nevertheless be susceptible to faecal contamination originating from nearby rivers during high discharge events if parameters such as filter efficiency or flow paths are not accurately considered (Pang 2009). In addition, there are few microbial field studies during high discharge events that can be used to validate these models in terms of bacterial hazard for drinking water extraction wells (Pang 2009).

Although there have been many studies on the processes influencing bacterial and viral transport and survival in porous material under laboratory conditions (John and Rose 2005), the behaviour of waterborne pathogens needs to be studied in the environment to assess actual water quality. Methods need to be developed to detect hazards such as riverine microbial contamination. The controlled conditions in laboratory studies are not able to reproduce the natural heterogeneity of environmental sites, which is a decisive factor in determining potential hazards for drinking water extraction wells (Regli et al. 2003; Frind et al. 2006).

As the detection of many of the waterborne pathogens requires complex analytical procedures (Brookes et al. 2005), Escherichia coli and Enterococcus sp. are often used as faecal indicator bacteria (FIB) for microbial pathogens in drinking water (Pronk et al. 2007). While useful as an established proxy for hygienic water quality and for background studies, where obtaining information on bacterial concentrations is not a question of time, the delay between sampling and obtaining the results of the FIB analysis is still too long to be useful in assessing actual water quality (Lin et al. 2008). Although there have been recent advances in real-time monitoring methods, they are not yet widely available for many applications (Marrone 2009). Flow cytometric methods require controlled environmental conditions and substantial investment for drinking water suppliers and are therefore problematic for decentralised applications. In such cases, alternative proxy indicators are required to assess actual water quality. Proxy indicators are parameters that are easier to measure or quantify than the variable of interest and have a well-known relationship with the variable. River water infiltration, for example, can be assessed by high-resolution monitoring of physical parameters, such as electrical conductivity or temperature, close to or in the river bed (Conant 2004; Vogt et 
al. 2010). Other researchers have identified proxy indicators for bacterial transport, including turbidity, particle density and size distribution, or the spectral absorption coefficient (SAC at $254 \mathrm{~nm}$ ) (Brookes et al. 2005; Pronk et al. 2007; Stadler et al. 2010). Many of these proxy indicators are applicable in karst systems, where the transport phenomena associated with precipitation events are different to alluvial aquifers, or require measurements in the river bed, increasing the susceptibility to damage due to mechanical stress, e.g. debris in the river or algal growth.

While many studies have established the relationship between high discharge or precipitation events and elevated bacterial concentrations, the resolution of the studies, bi-weekly or less frequent, is insufficient to show the temporal development of faecal indicator bacteria concentrations during sudden high discharge events (Grisey et al. 2010; Nnane et al. 2011). However, drinking water extraction well management requires information on actual water quality with a sufficiently high time resolution to enable management options, such as turning off extraction pumps, to be carried out properly. Therefore, the need arises to identify proxy indicators that can be used to assess actual water quality and describe the development of microbial contamination during a high discharge event.

The overall aim of this study was to provide a basis for assessing actual groundwater quality by combining proxy indicators for river water infiltration and short- term microbial monitoring studies in an alluvial aquifer while focussing on the spatial and temporal dynamics of the proxy indicators. The specific objectives were (a) to investigate the spatial and temporal development of FIB concentrations in riverine groundwater following a high discharge event and (b) to identify proxy indicators best used as surrogates for bacterial contamination in an alluvial aquifer.

\section{Methods}

\subsection{Study Area and Measurement Set-up}

The study area is located in the lower Birs Valley of Northwest Switzerland (Fig. 1). It is an alluvial system with a shallow, coarse, gravelly aquifer. The River Birs was canalised at the end of the nineteenth century, and since then, the river bed level has declined by several metres into the former floodplain, from which it was subsequently disconnected. The River Birs runs $75 \mathrm{~km}$ through the Swiss Jura and joins the River Rhine in Basel, creating a catchment area of 866 $\mathrm{km}^{2}$. The mean annual flow near the confluence zone of the tributary Birs with the Rhine is $15.4 \mathrm{~m}^{3} \mathrm{~s}^{-1}$ and storm flows can reach up to $383 \mathrm{~m}^{3} \mathrm{~s}^{-1}$.

The aquifer material mainly consists of carbonate gravel: it is a well-rounded, variably sorted sediment with few layers of clay and silt in between, resulting in a

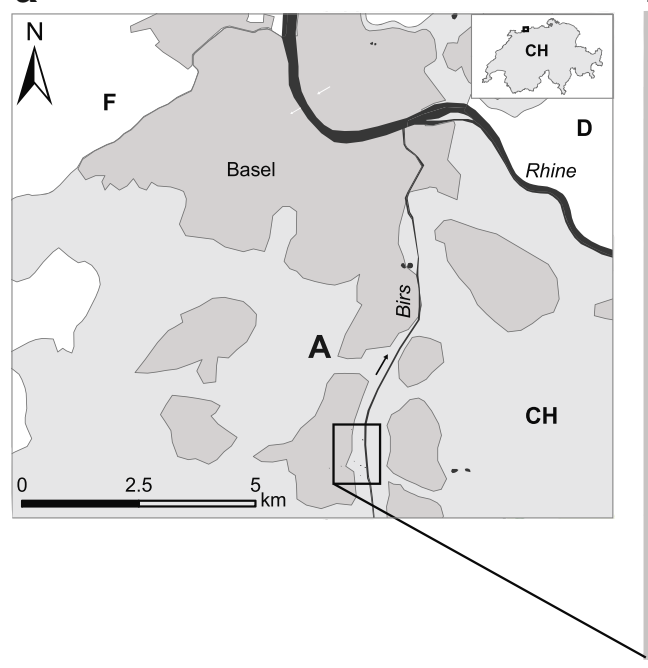

b

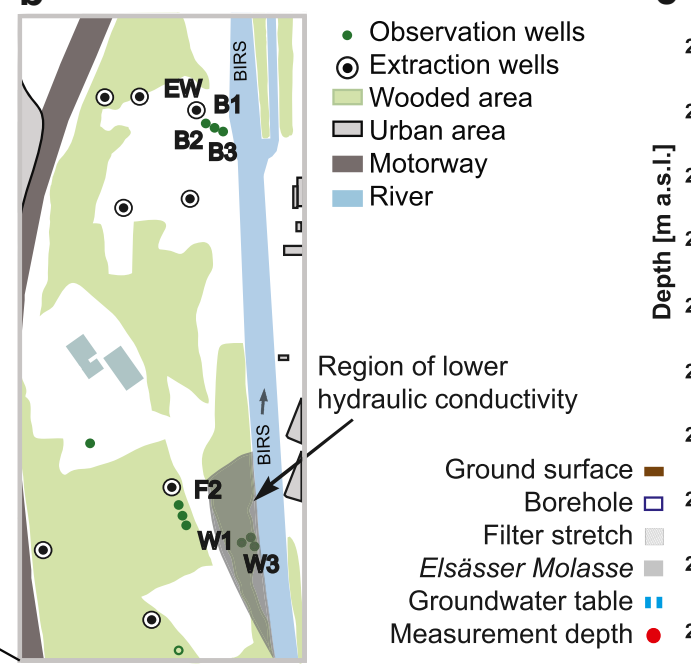

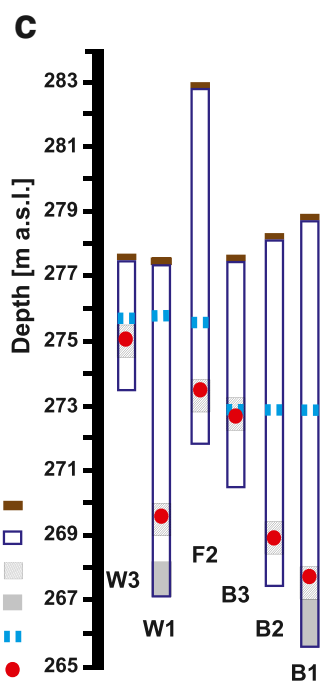

Fig. 1 a, b Map views of the location of the six observation wells, the river and the drinking water extraction wells. $\mathbf{c}$ The installation depths of the instruments and filter stretches in the observation wells relative to the surface topology and aquifer bottom (where reached) 
a large variance in hydraulic properties. The carbonate gravel components of the aquifer are of Triassic and Jurassic origin with hydraulic conductivities from $3 \times$ $10^{-3}$ to $10^{-2} \mathrm{~ms}^{-1}$. Hydrogeophysical investigations indicated the location of a region with low hydraulic conductivity $\left(\sim 4 \times 10^{-3} \mathrm{~ms}^{-1}\right)$ (shaded area in Fig. 1). The aquifer bottom is formed by an aquitard and consists of Tertiary deposits of Elsässer Molasse (bedrock), with very low hydraulic conductivities $\left(10^{-8}\right.$ to $10^{-5} \mathrm{~ms}^{-1}$ ). The maximal depth to groundwater is 29 $\mathrm{m}$ and the thickness of the saturated zone varies between 0.6 and $10 \mathrm{~m}$.

The aquifer recharge is mostly from river infiltration, lateral inflow from the local catchment area and intermittent artificial recharge. Eight active extraction wells in the study area (Fig. 1) supply of $5 \times 10^{6} \mathrm{~m}^{3}$ drinking water per year to six communities, comprising approximately 51,000 people.

The experimental site for river-groundwater interaction was located in the vicinity of the river bank (Fig. 1). Groundwater head, temperature, turbidity and electrical conductivity were recorded in the groundwater observation wells and in the river. Measurements were taken automatically every 30 min using multiparameter instruments (YSI 600 OMS V2). To address the scale and dynamics of the river-groundwater interaction, three observation wells (B1, B2 and B3) in the experimental site were equipped to monitor additional quality parameters (all Endress+ Hauser single parameter instruments): number of particles within the size range of $2-10 \mu \mathrm{m}$ and $\mathrm{SAC}$ (at $254 \mathrm{~nm}$ ).

\subsection{Microbial Sampling and Analysis}

Six groundwater observation wells, one drinking water extraction well (EW, Fig. 1) and the river were sampled for E. coli and Enterococcus sp. The river, the observation wells in the alluvial forest (W1, W2) and observation well F2 were sampled manually using a PVC tube and wet-pit pump. Before each sample was taken, the tube was flushed to replace the volume of water in the observation well. The samples from the extraction well were taken from the untreated groundwater in the water chamber. All samples were stored in polyethylene bottles containing thiosulfate and kept cool at $4^{\circ} \mathrm{C}$ before being analysed within $8 \mathrm{~h}$ of collection. The observation well cluster B1, B2 and B3 was also equipped with an automated sampler cooled to $4^{\circ} \mathrm{C}$ (Endress + Hauser ASP 2000). Sterilised glass bottles $(1.51)$ were used in the automated sampler.

Hygienic water quality was assessed for all samples by standard methods complying with the Swiss Food Manual (ISO 16649-1, BAG 2004).

Sample volumes of 1, 10 and $100 \mathrm{ml}$ were filtered through cellulose nitrate membrane with a pore size of $0.45 \mu \mathrm{m}$ (Microsart CN-Filter 11406Z-50 SC). To analyse $E$. coli concentrations, the filters were first incubated on Tryptone Soya Agar (Oxoid CM0131) for $2 \mathrm{~h}$ at $37^{\circ} \mathrm{C}$ and then transferred to the selective T. B.X agar (Oxoid CM0945). The plates were incubated for $18-24 \mathrm{~h}$ at $44^{\circ} \mathrm{C}$. The colonies were counted and normalised to E. coli colony forming units (CFU) 100 $\mathrm{ml}^{-1}$. To monitor Enterococcus sp., the filters were placed onto Chromocult Agar and incubated for 24 $\mathrm{h}$ at $37^{\circ} \mathrm{C}$. The colonies were counted and normalised to enterococcal CFU $100 \mathrm{ml}^{-1}$.

\subsection{Filter Efficiency}

The filter efficiency $(\lambda)$ of the aquifer was calculated according to Eq. 1 (based on Matthess et al. 1988).

$\lambda=-\frac{\ln \left(\frac{\mathrm{C}_{\mathrm{p}}}{\mathrm{C}_{\mathrm{o}}}\right)}{x_{\mathrm{h}}}$

where $C_{\mathrm{o}}$ is the concentration in the next observation well towards the river, $C_{\mathrm{p}}$ the concentration in the observation well further away from the river and $x_{\mathrm{h}}$ the horizontal flow length between the two observation wells.

\section{Results}

\subsection{Bi-weekly Monitoring}

To determine the behaviour and background concentrations of the faecal indicator bacteria species $E$. coli, two samples a week were taken between 9th June and 23rd July 2009. In total, 45 samples were taken from two groundwater observation wells and the river. The monitoring period in June/July 2009 included average discharge situations and two clusters of high discharge events with over $80 \mathrm{~m}^{3} \mathrm{~s}^{-1}$ peak discharge (Fig. 2). Groundwater head was strongly influenced by the pumping regime in nearby extraction wells: daily head fluctuations due to the diurnal extraction regime 


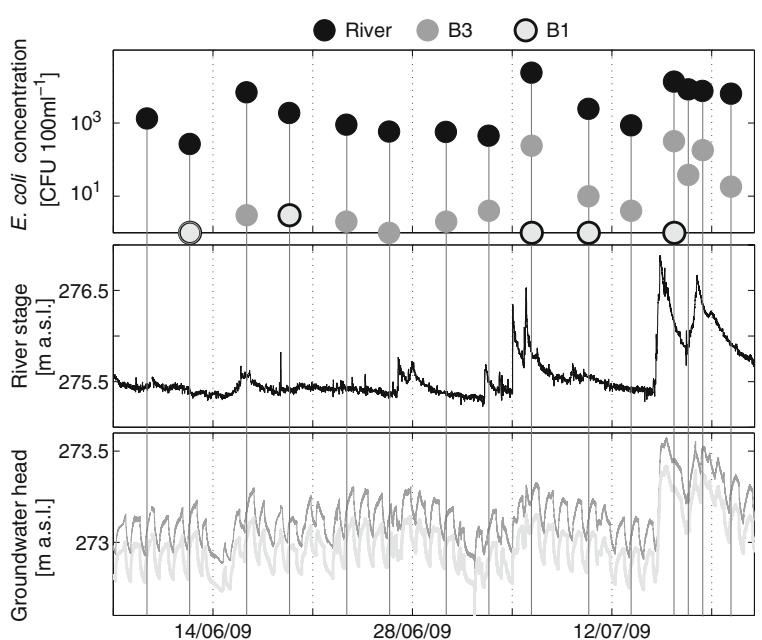

Fig. 2 E. coli counts from the bi-weekly monitoring in the river and two groundwater observation wells in June/July 2009 (top). The river stage with the high discharge events in the last third of the sampling period (middle). The groundwater head was heavily characterised by diurnal groundwater pumping regime in the nearby drinking water extraction wells (bottom graph)

reached up to $0.2 \mathrm{~m}$. The bacterial sampling results showed clear indication of elevated $E$. coli in the river during the high discharge events (Fig. 2), whereby bacterial concentrations increased by up to an order of magnitude. Concentrations in the river ranged between 600 and 2,000 CFU $100 \mathrm{ml}^{-1}$ during average discharge situations and reached 13,700 to 24,100 CFU $100 \mathrm{ml}^{-1}$ during the high discharge events. The bacterial concentrations counted in groundwater samples taken in B3, the observation well closest to the river $(10 \mathrm{~m})$, were increased by up to two orders of magnitude following high discharge events, reaching up to $300 \mathrm{CFU} 100 \mathrm{ml}^{-1}$. Bacterial concentrations in the samples taken from B1 (17 $\mathrm{m}$ from the river) were low and comparable to concentrations in $\mathrm{B} 3$ before the two major high discharge events during the monitoring period. The low bacterial concentrations found in both groundwater observation wells ( 0 to $3 \mathrm{CFU} 100$ $\mathrm{ml}^{-1}$ ) were classed as background levels of $E$. coli for these observation wells.

\subsection{Event-Based Sampling}

The event-based experiment was carried out during a high discharge event, between 6th and 9th May 2010. Although the event was only small compared to the range of discharge events in 2010 (less than $40 \mathrm{~m}^{3} \mathrm{~s}^{-1}$ peak discharge), it was the first one after a longer period of little precipitation and low river stage. In total, 86 water samples were taken from six groundwater observation wells, the river and a drinking water extraction well. Figure 3 shows the sampling frequency and river stage. During the event, the maximum precipitation intensity was $40.8 \mathrm{~mm} \mathrm{~h}^{-1}$, however only for approximately $30 \mathrm{~min}$.

The highest concentration of FIB was found in the water sampled from the river. None were found in the water sampled from the EW and no E. coli and only two enterococcal CFU were found in the observation well $95 \mathrm{~m}$ away from the river (F2). The average FIB concentrations and standard deviation in the groundwater decreased with increasing distance of the sampled well from the river (Fig. 4). Of the other five groundwater observation wells, $\mathrm{W} 1$ yielded the lowest bacterial concentrations and the smallest standard deviation. In comparison to the results from the monitoring period in 2009, bacterial concentrations in B1 were elevated during the high discharge event.

Compared to FIB concentrations in the river, FIB concentrations in groundwater were reduced by approximately two orders of magnitude in the first of the observation wells in the B cluster (B3, $10 \mathrm{~m}$ from the river bank) and one order of magnitude in the $\mathrm{W}$ cluster (W3, $4 \mathrm{~m}$ from the river bank). A further reduction by one order of magnitude was observed between $\mathrm{B} 3$ and $\mathrm{B} 1$ ( $7 \mathrm{~m}$ distance) and by two orders of magnitude between $\mathrm{W} 3$ and $\mathrm{W} 1$ (5 $\mathrm{m}$ distance) (Fig. 4).

The filter efficiency for each well is shown plotted against distance of the observation well to the river in

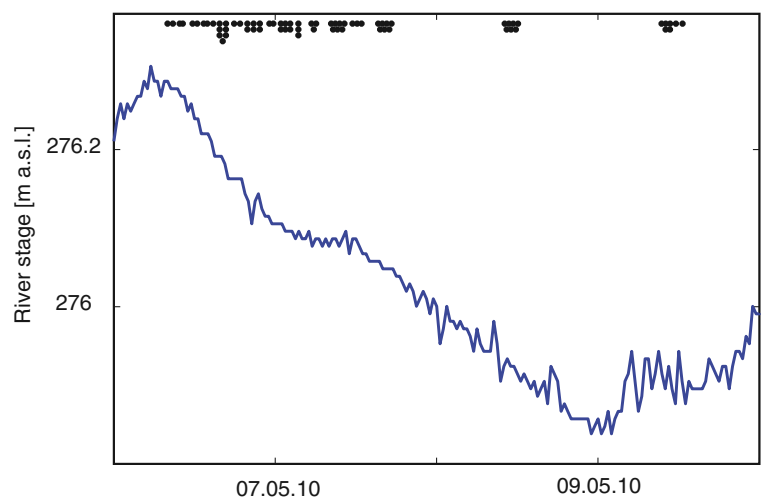

Fig. 3 The black dots represent water samples from the river and groundwater during the event-based sampling period in May 2010. The water samples were taken at different intervals, depending on the river stage. The highest sampling frequency coincided with the initial decrease in the river hydrograph 
Fig. 4 Faecal indicator bacteria (E. coli and Enterococcus sp.) concentrations in river and groundwater during the event sampled in May 2010 (6th-9th, see Fig. 3). Average and standard deviation of samples decrease with increasing distance from the river. The overall reduction of concentrations amounts to approximately three $\log$ scales within $20 \mathrm{~m}$ of flow path in the aquifer

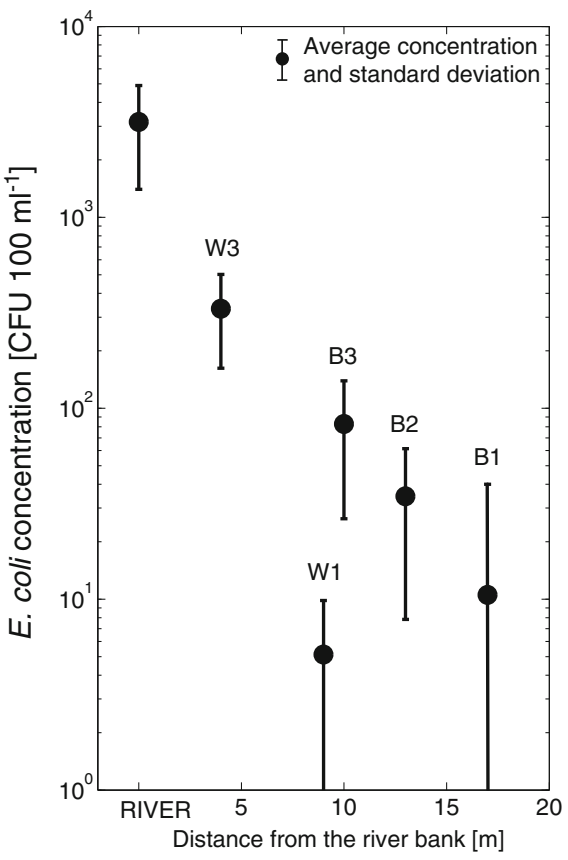

Fig. 5. The highest filter efficiencies (W3 $5.41 \times 10^{-2}$ ) were found closest to the river and the lowest filter efficiency furthest away from the river (B1 $1.11 \times 10^{-3}$ ). The best fit is given by a quadratic function (total residual 0.0158) compared to a linear function (residual 0.0346).

Figure 6 shows the temporal development of $E$. coli concentrations during the sampling period. The highest concentrations were observed at the

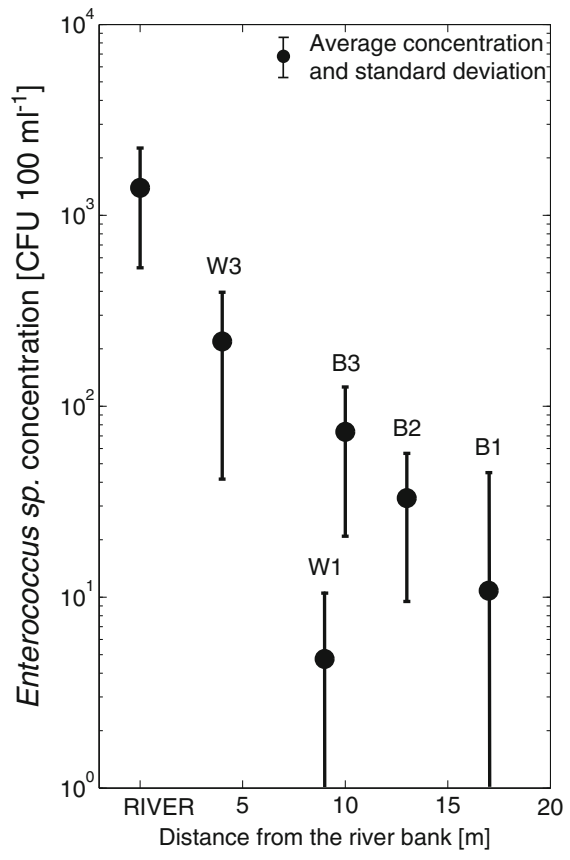

Fig. 5 Filter efficiency $(\lambda)$ of the aquifer shown in relation to observation well distance from the river bank (horizontal) with a quadratic function fit

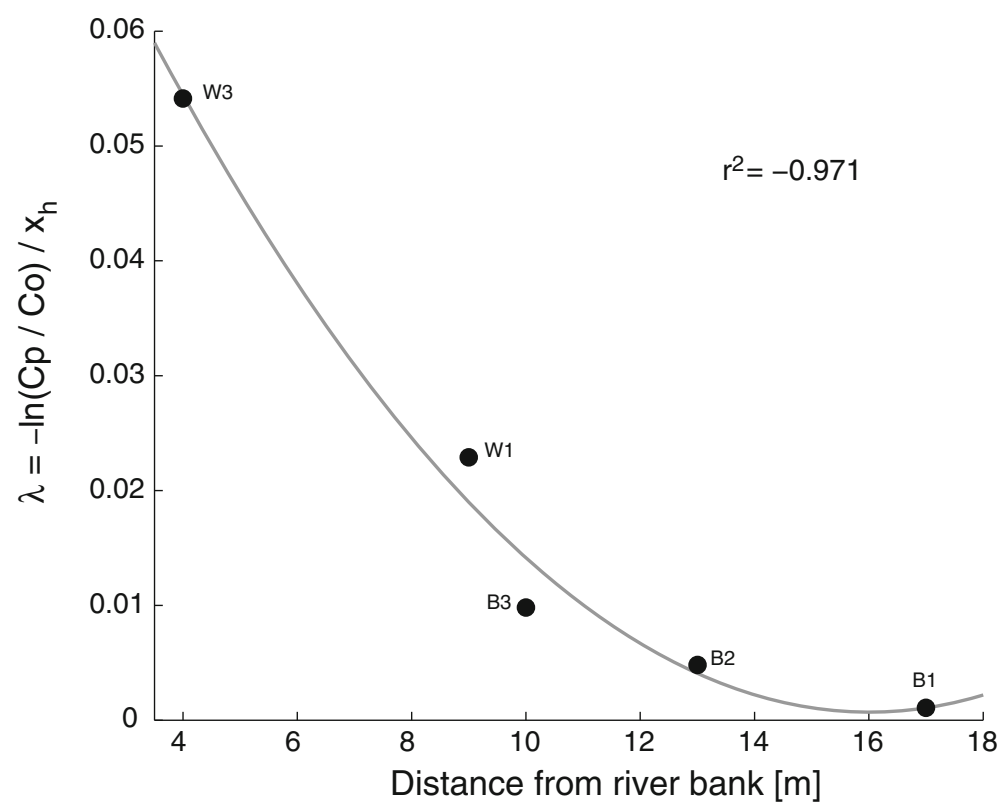

beginning of the sampling period, the lowest at the end. The concentrations in the B cluster (B1, B2 and B3) were reduced to background levels, as observed during the monitoring period in June/July 2009, within 3 days, while E. coli concentrations in the river also remained elevated $(3,200 \mathrm{CFU}$ $100 \mathrm{ml}^{-1}$ ) compared to background concentrations observed in June/July 2009. 
Fig. 6 Temporal development of E. coli concentrations in groundwater during the sampling period in May 2010 (6th-9th)

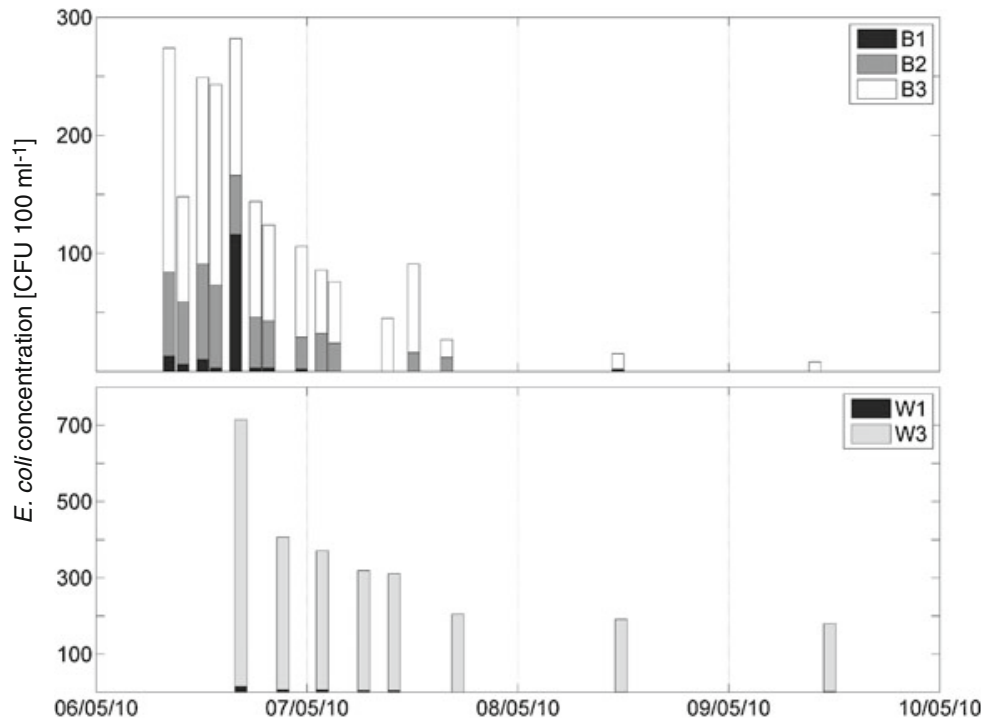

Six time-series of continuously measured parameters were used to assess the suitability of the different parameters to serve as proxy indicators for faecal contamination of groundwater. These were groundwater head, temperature, electrical conductivity, turbidity, particle density and SAC.

All time-series shown in Fig. 7 were recorded in observation well B3 during the event-based sampling. The large peaks observed in groundwater head are characteristic of the pumping regime in the groundwater extraction wells. The smaller, more frequent peaks are related to the individual pattern of extraction and the distance between the observation well B3 and each extraction well. Extraction (by one or more pumping stations) is usually started around 4 p.m. and ceased by 6 a.m. Any increase in groundwater head was partly masked by the regular pumping regime, which resulted in approximately $0.15 \mathrm{~m}$ fluctuations in groundwater head and no clear peak associated with the elevated river stage. The changes measured in the other parameters during the high discharge event in the river were more easily detected. Groundwater temperature ranged between $10^{\circ} \mathrm{C}$ and $12^{\circ} \mathrm{C}$ and increased gradually after a small decline at the beginning of the sampling period. Electrical conductivity ranged between 480 and $570 \mu \mathrm{S} \mathrm{cm}$. River water electrical conductivity was lower than groundwater electrical conductivity, leading to a characteristic decrease indicating the arrival of rapidly infiltrating river water at the groundwater observation well. Turbidity increased slightly (from 0.55 to $0.75 \mathrm{NTU}$ ), while particle count increased fourfold (the highest concentrations were recorded towards the end of the sampling period). SAC increased slightly and showed a similar behaviour to turbidity, although the peak occurred after the peak in turbidity (approx. $3.5 \mathrm{~h}$ later). Peak FIB concentrations occurred before the peaks in SAC and turbidity and during the decreasing phase of the electrical conductivity (Fig. 7).

\section{Discussion}

\subsection{Bi-weekly Monitoring vs Event-Based Sampling}

During both sampling periods, the FIB concentrations in the river and groundwater were 10- to 100 -fold greater during and shortly after a high discharge event and subsequently decreased. The event-based sampling took place during a minor event with less than $40 \mathrm{~m}^{3} \mathrm{~s}^{-1}$ peak discharge, but after a long period (1 month) without discharge-effective precipitation. Without this natural source of recharge, both the river stage and the groundwater table were relatively low in the study area. After studying drinking water sources in the UK associated with disease outbreaks and affected by river water infiltration or the washout of animal faeces, Nichols et al. (2009) associated these conditions - low level rainfall for a few weeks prior to excess rainfall-with an increase in waterborne 


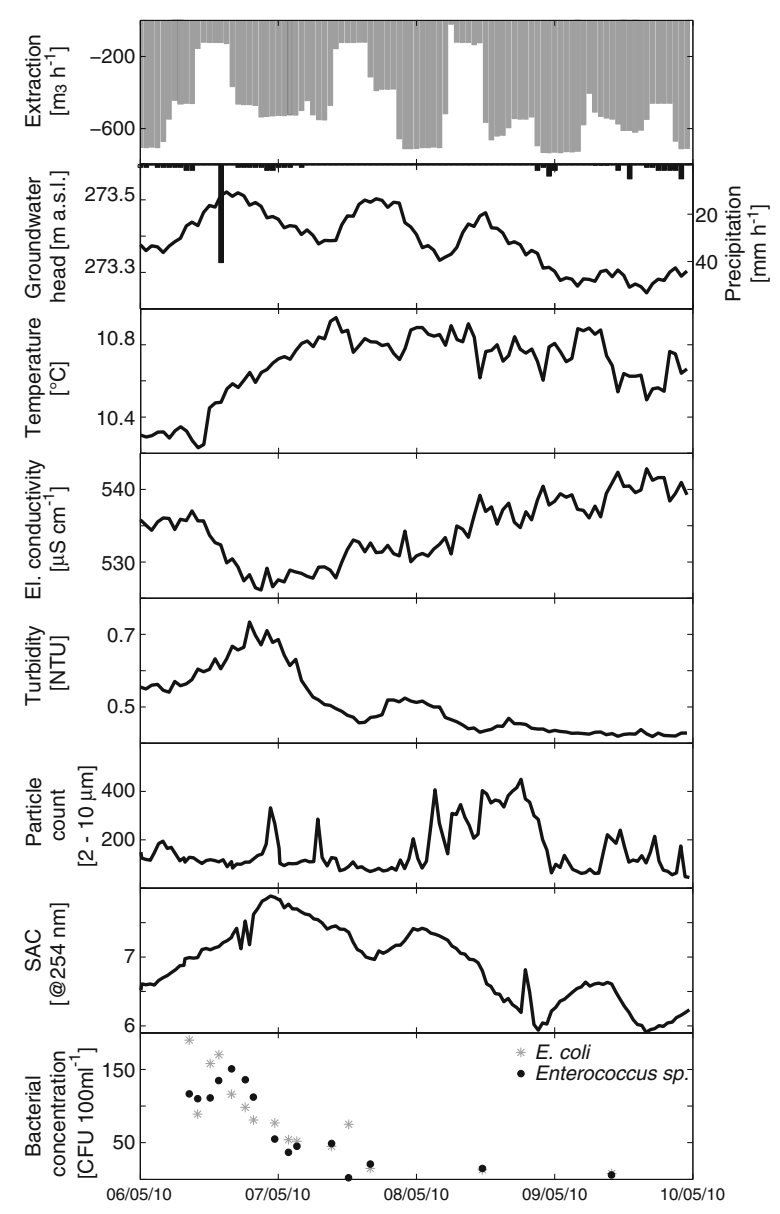

Fig. 7 Comparison of E. coli and Enterococcus sp. concentrations with time-series of continually monitored groundwater parameters (turbidity, SAC, particle count, electrical conductivity, temperature and river stage) recorded in observation well B3

disease bacteria concentrations in groundwater following a precipitation-induced increase in river stage.

Although the $E$. coli concentrations in the river were higher during the bi-weekly monitoring period than they were during the event-based monitoring and peak river discharge was double during the bi-weekly sampling, the bacterial concentrations observed in the groundwater samples taken during the bi-weekly monitoring study were comparable for B3 but low for B1.

This discrepancy indicates that the bi-weekly monitoring was not able to detect high bacterial concentrations present at the beginning of an event, thus emphasising the strong 'hit-and-miss' characteristic of this approach.

The high frequency of sampling during the eventbased monitoring period in May 2010 provided more information on the development of bacterial concentrations during a high discharge event and is therefore better suited for studying the relationship between river-groundwater interaction and FIB concentrations, as well as for detecting potential contamination due to infiltrating river water during a high discharge event.

\subsection{Temporal Development During High Discharge Event}

The highest $E$. coli concentrations have been associated with the rising limb of a river discharge hydrograph, followed by a rapid return to concentrations similar to those prior to the event (Wilkinson et al. 1995). In addition to this 'first flush' phenomenon, i.e. high FIB concentrations in the river/groundwater early in the discharge event, the highest infiltration from the river to the aquifer occurs during the rising limb and immediately after the peak river stage (Mutiti and Levy 2010). In agreement with these observations, the highest bacterial concentrations in this study were found in the river and at the beginning of the eventbased sampling in May 2010. The FIB concentrations in the B cluster and W1 decreased to low, or background levels (as observed during the monitoring period in June/July 2009) within 2 days. Although $E$. coli and Enterococcus sp. can survive for a limited period of time in groundwater, their viability decreases by half in under $24 \mathrm{~h}$ (McFeters et al. 1974). The sustained higher concentrations towards the end of the event-based sampling in W3 suggest that the connectivity between the river and the aquifer was retained in the proximity of this observation well. In this case, connectivity can be defined as high hydraulic conductivity and hydraulic gradients favouring river water infiltration. The combination of these two factors and small distance between river and sampling point resulted in a prolonged infiltration period and high bacterial concentrations.

The filter efficiency $(\lambda)$ decreased with increasing distance from the river. The data from the observation wells further away from the river bank $(>10 \mathrm{~m})$ were comparable to the results from other studies with similar hydrogeological settings and distances from the river (Pang 2009). The two observation wells in the $\mathrm{W}$ cluster, which were closer to the river and in a region with higher hydraulic conductivity, showed a higher filter efficiency. The filter efficiency calculated for these observation wells was more similar to studies 
that had also recorded microbes closer to the river; however, none had studied E. coli distribution at distances under $10 \mathrm{~m}$. The two clusters (B and $\mathrm{W}$ ) showed different removal rates, i.e. attachment and inactivation of faecal indicator bacteria from the water column (Gronewold et al. 2011). The difference in filter efficiency was most noticeable in wells B3 and $\mathrm{W} 1$, which differed by a magnitude although they were located at approximately the same distance from the river. The filter efficiency continued to decrease with increasing distance from the river bank underlining the importance of the river bed and bank in removing a large amount of microbial load from the infiltrating river water. While Regli et al. (2003) observed FIB concentrations during events at 15-120 m distances from the river on a daily basis, this paper observed FIB concentrations in the near river zone, from 4 to $17 \mathrm{~m}$ from the river at a higher temporal resolution (2-4 hourly). Close to the river, we observed a strong linear dependence of FIB on distance. FIB removal with distance became non-linear further away from the river, as previously reported by Regli et al. (2003). The high removal rate observed for W1 probably originates from the hydrogeological properties of the aquifer. The upper and lower aquifers in the area around the $\mathrm{W}$ cluster are separated by an approximately 2-m-thick layer of overbank deposits, dominated by fine fraction sediments $(<0.063 \mathrm{~mm})$ with variable gravel content. The filter stretches of W1 and W3, representing the depth in the aquifer from which the water sample originated, were thus separated by an additional barrier to the FIB. Fine sediments have a higher porosity than sand and an increased clay content can provide greater pore continuity, but the hydraulic conductivity is smaller (Unc and Goss 2003). The aquifer composition in the proximity of B1, B2 and B3 was more homogeneous, with a lower fine sediment fraction than around W1 and W3. The higher hydraulic conductivities, as indicated in Fig. 1, and the lower removal rates in the proximity of B1, B2 and B3 pose a threat to the nearby drinking water extraction wells. Although the filter efficiencies observed in the W cluster were higher, large local variances in hydraulic conductivity, such as caused by the overbank deposits, can give rise to fast or preferential flow paths, along which microorganisms can be transported over great distances (Regli et al. 2003). The results from this area around the $\mathrm{W}$ cluster are characteristic for the observation wells sampled (W1 and W3); however, the results from the B cluster are likely to represent a greater proportion of aquifer. Although no bacterial colonies were found in the extraction well sampled, a greater or longer high discharge event may cause problems, especially considering potential preferential flow paths. Further studies should therefore include a range of hydrological situations, especially high discharge situations after long periods of dry weather.

\subsection{Proxy Indicators}

The suitability of different parameters to serve as proxy indicators for microbial contamination was investigated in addition to assessing the actual microbial contamination, based on FIB. While many of the continuously measured parameters showed a response to the high discharge event in the river, the timing differed, giving, for example, different rates of increase or time-to-peak measurements. Peaks in some of the parameters frequently associated with microbial transport, e.g. turbidity and SAC (Stadler et al. 2010), occurred during the decreasing limb of microbial concentration. According to Stadler et al. (2010), the passage of event water (i.e. water infiltrating following a precipitation event) through the humic substancerich soil layer is a determining factor for the correlation between SAC and bacterial peaks. The delay observed between the peaks in microbial concentration and SAC in this study indicates that the small increase in groundwater head could not leach sufficient organic matter from the aquifer material to induce an increase in SAC. The initial SAC increase observed presumably originated from the river and allochthonous sources of organic matter. The subsequent SAC peak occurs after the groundwater head has reached its maximum and represents a combination of river water and autochthonous sources of SAC, while the bacterial concentration is only related to the infiltrating river water. Turbidity can reflect both SAC and the presence of particles and thus it is a sum parameter. Although turbidity peaked before SAC, indicating an alternative source of turbidity (possibly inorganic matter), the peak was still after the peak in bacterial concentration. Both turbidity and SAC peaks were strongly dependent on groundwater head and the associated pressure wave. Particle densities were highest towards the end of the event-based sampling period and therefore not applicable as proxy indicators for 
potential microbial contamination in groundwater. The size range used in this study may have influenced the applicability, as it covers the top of the range of particle sizes useful as indicators for bacterial concentrations defined in other studies: Pronk et al. (2007) found $E$. coli peaks correlating well with particle sizes between 0.9 and $2.5 \mu \mathrm{m}$. Although both electrical conductivity and temperature reacted to the high discharge event, by a decrease in the former and an increase in the latter, they were not directly related to FIB concentrations. In addition to the individual behaviour during the high discharge event, the reaction of each parameter is dependent on external factors, e.g. temperature shows seasonal variation and a strong relationship to river water temperature, while electrical conductivity is additionally affected by precipitation events and therefore not an ideal tracer for river water infiltration. The occurrence of pathogenic microorganisms also shows a non-linear relationship with river discharge and groundwater flow, for example, Wilkinson et al. (1995) found the highest concentration of $E$. coli during the rising limb of a river discharge hydrograph and then a rapid return to concentrations similar to those prior to the event. In addition, the relationship between river discharge and microbial concentration can also be affected by dilution effects (ten Veldhuis et al. 2010).

The high-resolution sampling and continuous parameter recording showed that no individual, continuously measured parameter was suitable for use as a proxy indicator for FIB, reflecting the high dimensionality of river-groundwater interaction, both in time and space. However, our investigations show that the onset of change in the time-series of each parameter showing a reaction to the high discharge event may be used in a proxy analysis. A non-static and non-linear proxy analysis can identify shifts in the time-series that indicate infiltrating river water, which would not be identifiable based on the analysis of an individual parameter. Multiparametric time-series are able to capture system state and therewith actual groundwater quality, but often result in large data sets with a high dimensionality, which are difficult to interpret without additional analysis. Such complex, multivariate data sets can be simplified and inherent patterns identified using a combination of a self-organising map and Sammon's projection (SOM-SM), giving rise to a neural network-based, non-linear method of statistical data analysis (Lischeid 2009). This methodology has frequently been used in fault detection systems of industrial processes and recently in a water distribution network (Mustonen et al. 2008). Further research in this area includes using this data set to test a multivariate SOM-SM approach to identify critical system states, where groundwater quality is degraded due to infiltrating river water (Page and Simovic 2011). The application of a SOM-SM method thereby reduces the complexity of a multivariate data set and allows realtime assessment of groundwater quality. The analysis can be used to detect shifts in groundwater quality induced by infiltrating river water, as it is based on variance in the measured time-series.

\section{Conclusion}

The aim of this study was to assess actual groundwater quality using two proxy-based approaches. The first approach was based on faecal indicator bacteria, while the second focussed on continuous time-series of groundwater measurements.

The focus of this study lay on the first $20 \mathrm{~m}$ of aquifer affected by river water infiltration. While many previous studies have focussed on distances greater than 20 m (Regli et al. 2003; Pang 2009), the results from this study demonstrated the relation between filter efficiency and distance from the river bed in the near river zone, where strong gradients in filter efficiency were observed. Bacterial concentrations were highest at the beginning of the event and decreased to background levels within 1-2 days. Lowresolution monitoring following high discharge events, as is often the case in practice, is therefore likely to miss peak bacterial concentrations in some, or all of the sampling points. Furthermore, high bacterial concentrations early in events may pose a considerable threat to drinking water quality, if the water suppliers are not informed in time to avoid extracting freshly infiltrating river water. In addition to transient bacterial concentrations in groundwater, the heterogeneity of hydraulic conductivities leads to complex flow and transport patterns, which cannot be interpreted based on only few microbial samples, hydrological situations or observation well time-series.

In addition to the event sampled, future event-based sampling experiments should therefore focus on highresolution early event sampling, i.e. during the rising 
limb of the river hydrograph, and include pre-event investigations of bacterial concentrations.

The second proxy analysis approach under investigation was based on the assessment of continuous time-series of six parameters. While the parameters all showed a reaction to infiltrating river water, none matched the behaviour of bacterial concentrations. We therefore propose combined analysis of a set of indicator parameters, such as electrical conductivity, temperature and SAC, to detect rapidly infiltrating river water. A SOM-SM analysis of a multivariate data set, including multiple observation wells and multiple parameters, can identify shifts in groundwater quality based on observed variance in the data set and provide the basis for an early warning system for the water supplier.

The connection between precipitation, high discharge events in the river and increased faecal indicator bacteria concentrations is well-established. However, investigations concerning the dynamics between the onset of increased river water infiltration and endangerment of drinking water wells require high-frequency event-based microbial sampling to highlight the transient character of bacterial density during a high discharge event. This study showed the importance of sampling frequency and knowledge of aquifer composition when conducting microbial sampling studies. The proposed methodology based on high-resolution sampling in combination with a multiparametric monitoring network and multivariate analysis removes the focus from a threshold-oriented, towards a process-oriented approach to groundwater quality management for drinking water extraction wells near rivers.

Acknowledgements We thank Endress+Hauser Metso AG and the Waterworks Reinach and Surroundings (WWRuU). This work was funded by the Swiss Innovation Promotion Agency CTI and the Freiwillige Akademische Gesellschaft Basel.

\section{References}

BAG. (2004). Schweizerisches Lebensmittelbuch (Swiss food manual). Bern: Bundesamt für Gesundheit.

Brookes, J., Hipsey, M., Burch, M., Regel, R., Linden, L., Ferguson, C., \& Antenucci, J. (2005). Relative value of surrogate indicators for detecting pathogens in lakes and reservoirs. Environmental Science \& Technology, 39(22), 8614-8621.
Conant, B. (2004). Delineating and quantifying ground water discharge zones using streambed temperatures. Ground Water, 42(2), 243-257.

Foster, S., \& Chilton, R. (2003). Groundwater: The processes and global significance of aquifer degradation. Philosophical Transactions of the Royal Society of London. Series B, Biological Sciences, 358(1440), 1957-1972.

Frind, E. O., Molson, J. W., \& Rudolph, D. L. (2006). Well vulnerability: A quantitative approach for source water protection. Ground Water, 44(5), 732-742.

Grisey, E., Belle, E., Dat, J., Mudry, J., \& Aleya, L. (2010). Survival of pathogenic and indicator organisms in groundwater and landfill leachate through coupling bacterial enumeration with tracer tests. Desalination, 261(1-2), 162168.

Gronewold, A. D., Myers, L., Swall, J. L., \& Noble, R. T. (2011). Addressing uncertainty in fecal indicator bacteria dark inactivation rates. Water Research, 45(2), 652-664.

John, D., \& Rose, J. (2005). Review of factors affecting microbial survival in groundwater. Environmental Science \& Technology, 39(19), 7345-7356.

Krause, S., Bronstert, A., \& Zehe, E. (2007). Groundwatersurface water interactions in a North German lowland floodplain-Implications for the river discharge dynamics and riparian water balance. Journal of Hydrology, 347, 404-417.

Kukkula, M., Arstila, P., Klossner, M., Maunula, L., vonBonsdorff, C., \& Jaatinen, P. (1997). Waterborne outbreak of viral gastroenteritis. Scandinavian Journal of Infectious Diseases, 29 (4), 415-418.

Lin, B., Syed, M., \& Falconer, R. A. (2008). Predicting faecal indicator levels in estuarine receiving waters-An integrated hydrodynamic and ANN modelling approach. Environmental Modelling \& Software, 23(6), 729-740.

Lischeid, G. (2009). Non-linear visualization and analysis of large water quality data sets: A model-free basis for efficient monitoring and risk assessment. Stochastic Environmental Research and Risk Assessment, 23(7), 977-990.

Marrone, B. L. (2009). Flow cytometry: A multipurpose technology for a wide spectrum of global biosecurity applications. JALA, 14(3), 148-156.

Matthess, G., Pekdeger, A., \& Schroetter, J. (1988). Persistence and transport of bacteria and viruses in groundwater-A conceptual evaluation. Journal of Contaminant Hydrology, 2, 171-188.

McFeters, G., Bissione, G., Jezeski, J., Thomson, C., \& Stuart, D. (1974). Comparative survival of indicator bacteria and enteric pathogens in well water. Applied Microbiology, 27 (5), 823-829.

McKergow, L. A., \& Davies-Colley, R. J. (2010). Stormflow dynamics and loads of Escherichia coli in a large mixed land use catchment. Hydrological Processes, 24(3), 276-289.

Mustonen, S. M., Tissari, S., Huikko, L., Kolehmainen, M., Lehtola, M. J., \& Hirvonen, A. (2008). Evaluating online data of water quality changes in a pilot drinking water distribution system with multivariate data exploration methods. Water Research, 42(10-11), 2421-2430.

Mutiti, S., \& Levy, J. (2010). Using temperature modelling to investigate the temporal variability of riverbed hydraulic conductivity during storm events. Journal of Hydrology, $388(3-4), 321-334$. 
Nichols, G., Lane, C., Asgari, N., Verlander, N. Q., \& Charlett, A. (2009). Rainfall and outbreaks of drinking water related disease in England and Wales. Journal of Water and Health, 7(1), 1-8.

Nnane, D., Ebdon, J., \& Taylor, H. D. (2011). Integrated analysis of water quality parameters for cost-effective faecal pollution management in river catchments. Water Research, 45, 2235-2246.

Page, R.M., Simovic, J. (2011). Statistical analysis of monitoring data. In Huggenberger, P., Epting, J. (Eds.), Urban geology. Basel:Springer

Pang, L. (2009). Microbial removal rates in subsurface media estimated from published studies of field experiments and large intact soil cores. Journal of Environmental Quality, 38, 1531-1559.

Pronk, M., Goldscheider, N., \& Zopfi, J. (2007). Particle-size distribution as indicator for fecal bacteria contamination of drinking water from karst springs. Environmental Science \& Technology, 41(24), 8400-8405.

Regli, C., Rauber, M., \& Huggenberger, P. (2003). Analysis of aquifer heterogeneity within a well capture zone, comparison of model data with field experiments: A case study from the river Wiese, Switzerland. Aquatic Sciences, 65(2), 111-128.

Stadler, H., Klock, E., Skritek, P., Mach, R. L., Zerobin, W., \& Farnleitner, A. H. (2010). The spectral absorption coefficient at $254 \mathrm{~nm}$ as a real-time early warning proxy for detecting faecal pollution events at alpine karst water resources. Water Science and Technology, 62(8), 18981906.

Taylor, R., Cronin, A., Pedley, S., Barker, J., \& Atkinson, T. (2004). The implications of groundwater velocity variations on microbial transport and wellhead protection-A review of field evidence. FEMS Microbiology Ecology, 48 (1), 17-26.

ten Veldhuis, J. A. E., Clemens, F. H. L. R., Sterk, G., \& Berends, B. R. (2010). Microbial risks associated with exposure to pathogens in contaminated urban flood water. Water Research, 44, 2910-2918.

Unc, A., \& Goss, M. J. (2003). Movement of faecal bacteria through the vadose zone. Water, Air, and Soil Pollution, 149, 327-337.

Vogt, T., Schneider, P., Hahn-Woernle, L., \& Cirpka, O. A. (2010). Estimation of seepage rates in a losing stream by means of fiber-optic high-resolution vertical temperature profiling. Journal of Hydrology, 380(1-2), 154-164.

Wilkinson, J., Jenkins, A., Wyer, M., \& Kay, D. (1995). Modeling faecal-coliform dynamics in streams and rivers. Water Research, 29(3), 847-855.

Zektser, I.S. and Everett, L.G. (2004). Groundwater resources of the world and their use. UNESCO IHP-VI, Series on Groundwater No. 6 